\title{
Historein
}

Vol $2(2000)$

Heterodoxies: Constructions of Identities and Otherness in Medieval and Early Modern Europe

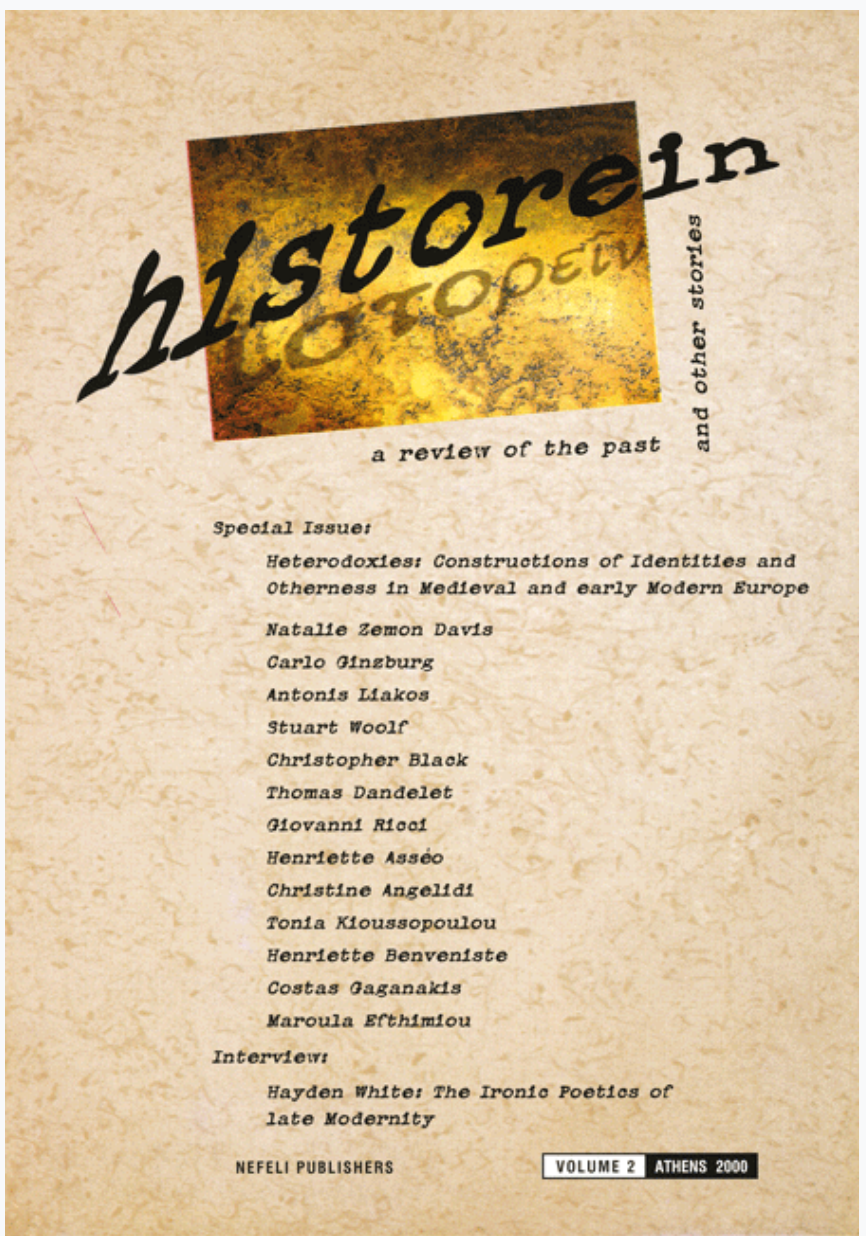

\section{Cursing with a Message: the Case of Georgios Karaiskakis in 1823}

Maroula Efthymiou

doi: $\underline{10.12681 / \text { historein.121 }}$

Copyright ( 2012, Maroula Efthymiou

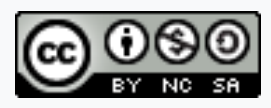

This work is licensed under a Creative Commons Attribution-NonCommercialShareAlike 4.0.

\section{To cite this article:}

Efthymiou, M. (2001). Cursing with a Message: the Case of Georgios Karaiskakis in 1823. Historein, 2, 173-182. https://doi.org/10.12681/historein.121 


\section{Cursing}

\section{with a message:}

the case of

Georgios

\section{Karaiskakis}

The bulk of the armed forces in the 1821 Greek Revolution was made up of illiterate or semiliterate peasants from the Peloponnese and central Greece.' Despite the fact that in the eighteenth and first quarter of the nineteenth century education and European Enlightenment had spread among Greeks more than among any other population of the Balkans, ${ }^{2}$ the majority of Greeks, living a rugged existence in the countryside, remained relatively uneducated, their ways cemented by centuries of ignorance and illiteracy.

Georgios Karaiskakis, the charismatic military leader of central Greece in the 1821 revolution, was one of these people. ${ }^{3} \mathrm{He}$ was the illegitimate son of a nun and a klepht*. He became a klepht too and found himself in the service of Ali Pasha in Ioannina, his aim being to become an armatolos in the mountainous region of the province of Agrafa, his place of origin. He was a brave and daring man of wit and invention as well as a military genius. He was irritable and ambitious, proud and magnanimous, prankish and persistent, tireless and incredibly forbearing where his illness, tuberculosis, was concerned. Karaiskakis - like several other chieftains from central Greecedid not join the war from the very beginning, and continued at times throwing himself whole-

\section{Maroula Efthymiou} heartedly into battle and at others trying to come to negotiations, either real or false, with the Turks.

Karaiskakis was no less rugged or uneducated than his fellow-soldiers were; yet, even amongst these rugged men, he was notorious for his loose tongue and the brazen torrents of obscenities he uttered. Thus, in late April-early May of 1823 , while addressing the messenger ${ }^{4}$ 
of the silihtar* Boda, the Albanian general who was at the time organising a corps of 5000 Moslem Albanians in an Ottoman attack on the Greek forces of central Greece, he said:

Come on, you shitty Turk... Come on you Jew, you pawn of the gypsies... Fuck your faith and your Mohammed. What did you think, you cuckolds... you should be ashamed to ask us sign a treaty with such a shitty Sultan Mahmud. I shit on him and your vezir and that Jew silihtar Boda, the whore. ${ }^{5}$

Before analysing the hidden meanings of this tirade, let us position it historically. In May 1823 Karaiskakis was with his army in the region of Agrafa, where he had managed to be appointed armatolos only a few months earlier. This was preceded by a period in which he had come into contact with the Turks to make a kapak* pact, a common practice among chieftains of central Greece during the revolution. ${ }^{6}$ The timing for the Ottoman forces was not good: during the first three years of the revolution and before the civil wars amongst the Greeks, the Greek forces had won many battles both on land and at sea. The silihtar Boda's army, which in the spring of 1823 had seen some action in central Greece, had to confront the vigilance of the Greek forces. Finding himself in a difficult position, and having violated the pact with Karaiskakis, the silihtar Boda sought to negotiate with him, the armatolos of Agrafa. This was when Karaiskakis let fly the torrent quoted above.

Of course Karaiskakis cursed and swore uncontrollably about everything and everyone in public, even about himself and his family. ${ }^{7}$ Furthermore, his cursing and swearing often bordered on delirium, so much that there is little point in looking for deeper meanings in such ranting. It is obvious, however, that the curses Karaiskakis uttered to the messenger were not directed towards him, as Karaiskakis himself states; they were directed towards the silihtar Boda and the Turkish command in general. And his tirade was not without meaning and coherence.

First and foremost, Karaiskakis's curses insult the religious faith of the silihtar. The first curse is raw and undisguised ["...I fuck your faith and your Mohammed..."]; the second consists of the derogatory 'shit' and 'Turk', a term denoting nationality, which at the time was used with a double meaning to describe the Moslem, even though he did not even perhaps speak Turkish, ${ }^{8}$ in precisely the same way the term 'Greek' was generally used to denote the Orthodox Christian subject of the Ottoman Empire, even if he did not speak Greek. ${ }^{9}$

These curses in themselves, regardless of the vulgar way they were expressed, conveyed a revolt. The Orthodox Christians of the Ottoman Empire had lived for centuries as second-class citizens, with the Moslems holding by right the position of first-class citizens. For centuries the former were obliged to show respect and humility towards their social and political superiors, thus stressing their inferiority.

These inter-relations of superiority and inferiority, power and subjection, were more clearly apparent in religious matters: as the faith of the powerful, the Moslem faith was superior and any 
slight against it was unimaginable, especially from the mouth of a dhimmi ( i.e. the non-Moslem subject of the empire). Any open insult against the Moslem faith not only meant insolence, defiance and disrespect, but also challenged the social balance by rejecting the status quo; it signified revolt. ${ }^{10}$

Cursing the Moslem faith so shamelessly and provocatively, Karaiskakis knew that within the ambiguity of his political stance at the time, he was sending a double socio-political message: that he, Karaiskakis, the armatolos of Agrafa, had been sorely insulted by the inconsistent violation of his pact with the Turks and for this reason he would not hesitate to go to extremes; that he, Karaiskakis, a struggler for Greek independence, was no longer a dhimmi, no longer a reaya*, no longer a second-class citizen who owed the prescribed respect towards the ruling religion and ideology; that he and his fellow-soldiers rejected, through their revolt, the old order of things, despised and would overthrow the previous social scheme and hierarchies under which they had lived and would obey the new scheme defined by the revolution. This is why he could now curse the whole of the Ottoman command, starting with the sultan and the silihtar Boda, who represent on the one hand the political inconsistency that had recently enraged him personally and on the other the former social status quo: i.e. what the Revolution itself was about.

The violence of his words was not unrelated to the latter, the political slant of the message. Karaiskakis belonged to the group of chieftains who for centuries operated in the Balkan mountains as brigands at the expense of the population of the countryside, as aggressors to the detriment of the Ottoman authorities, or as law-abiding subjects on the side of the Ottoman administrative machine, being designated as armatoloi and regional guards. In an ongoing game of subjection and mutiny, co-operation and disobedience, these toughened people developed mechanisms of connections and relations with the Ottoman rulers, which varied according to the circumstances, ranging from provocation and conflict to subjection and subservience."

This dual game was not unknown to Karaiskakis in the pre-revolution era as it was not generally unknown during the first years of the revolution. Like many other armatoloi and chieftains of central Greece who were active in border regions between those under Ottoman control and those under the control of the revolutionaries, Karaiskakis played the double role of the rabid enemy of the Ottoman powers and that of the subservient negotiator. ${ }^{12}$ The kapak pacts, which the chieftains of central Greece occasionally made with the Ottomans ${ }^{13}$ even during the course of the revolution, were one of the problems in the struggle for independence. At the time of the event in question, Karaiskakis found himself at an important crossroads as regards the realisation of his position and his involvement in the revolution. At every obstacle in his relations with the Ottomans he came closer to rebelling against his former double role and approached a clearer and more absolute acceptance of the revolution, its ideals and its potential. In this sense, adding the word 'shit' to the appellation of the sultan, Karaiskakis, in his own notoriously rude manner, illustrated his newly-acquired socio-political and administrative stance: from a servant to the 
Ottomans, he rebelled to become the avenger of freedom, rising to leadership. It is from this new standpoint that he could now attack his former bosses with his most venom-dipped arrow, the grave insult 'Turk'.

For an insult to hit home, it must be interpreted as such by both parties - sender and receiver. And strange as it may seem, this was the effect of the term 'Turk' in its national meaning. In the long centuries of Ottoman rule, and in the melting pot of a multi-national and multi-religious empire whose members had been separated by virtue of their faith, national terms took on a meaning which differed greatly from the meaning they acquired in the 19th and 20th centuries, times of development and maturation of nationalism. As Turkish nationalism was virtually the last to develop in relation to that of other peoples of the Balkans, for centuries the term 'Turk' was used to denote the Turkish-speaking common man, the simple-minded, ignorant, wretched and humble subject of the empire in contrast to those who staffed Ottoman administration and army. For the latter, the position of common Turk was lowly and contemptible and they vehemently differentiated themselves from him. These officials, irrespective of their mother tongue and place of origin, received special training, learned to speak contrived and stiff officialese, were not taxed and through their position had personal connections with the sultan. They were the Osmanlis. They were the leaders and not the led; they were powerful, not powerless; intelligent, not simpletons; educated, not ignorant; significant, not negligible. They were not, in other words, by any means, 'Turks'. ${ }^{14}$ And this applied to the vezir and the sultan as well as to the silihtar Boda, the Ottoman official of Albanian descent, and his messenger. ${ }^{15}$

Calling these Ottoman officials 'Turks', Karaiskakis hit home using their own weapons, degrading them socially and deposing them from their position. As 'Turks' they were no longer commanders, no longer superior, no longer worthy of respect; they were commoners devoid of authority and power. All that not just as 'Turks', but worse: as 'Jews' too.

As opposed to the Jews of western Europe, the Jewish population of the Byzantine and the Ottoman Empire enjoyed relative security and social tolerance. Their relatively good position notwithstanding, they were for the Moslem and the Christian subjects of the Ottoman Empire an object of extensive prejudice and the butt of contempt and ridicule. Yet they were considered productive despite being regarded as misers and cowards. ${ }^{16}$

In Ottoman society, however, where the connections between civil and military authorities ran deep, the term 'Jew', implying the above-mentioned traits, functioned in the same way as the term 'Turk': it undermined the officials' social and military existence. Officials, usually former or future members of the military, could not be cowardly; much less so an official of Albanian descent as the silihtar Boda was. Social power in the Ottoman society was built on personal relations of protection of the powerless by the powerful. Generosity and magnanimity were expected traits of any socially important person from the Sultan down to the local ayan. Miserliness and cowardliness - the essence of the insult 'Jew' - were just the opposite. 
It was even worse to be 'a Jew, pawn of the gypsies'. In the popular belief of the Moslems, Christians and Jews of the empire there was no more disreputable, parasitic and despicable creature than the gypsy. ${ }^{17} \mathrm{An}$ official who was miserly and cowardly (like a 'Jew') and the pawn of the most immoral person (a 'gypsy'), was a social 'nothing', a military zero. He was morally debauched and socially demeaned; he was a combination of the 'Jew' (cowardly like a woman) and the gypsy (a nothing like a prostitute): he was a 'whore'.

If Karaiskakis confronted his foes with such a torrent of insults, offending their world and society, then where did he belong and what world did he represent? The mere type of curses, due to the disdain they contained, definitely implied that since they were supposedly true of the Ottomans, then they did not apply to the Greeks. Karaiskakis was not a 'shit', or a 'Turk' or a Moslem or a 'Jew' or a 'gypsy' or a 'whore', not in the meaning he gave to these terms. He stressed this, in any case, when he said in another instance addressing the Turks:

You cuckolds! The ones you captured were your own men; they were Turks and Jews because that's what reayas means. Behold the Greeks! They shit on you now and forever! ${ }^{18}$

Karaiskakis was therefore a Greek precisely because he was not what he specified his enemies as being. According to him, the traits of the Greeks were that they were not cowardly and submissive like the Turks and the Jews; on the contrary the characteristic of the Greeks was to be brave, proud and ready to rebel against any oppression. Karaiskakis was a Greek and this was something that both he and the majority of the Greek population had just started to realise; they were no longer the Romioi (= Rumlar, Romans), nor were they Graikoi as they were called during the Byzantine and Ottoman Empire. They were Greeks (Hellenes), a fluid term which was for many centuries one with ancient Greek paganism. Although the term had taken on a negative connotation in the 4th century $A D$ due to the spread of Christianity, it was temporarily rediscovered during the last two centuries of the Byzantine era and regained its former glory through western European renaissance and enlightenment.

In the second half of the eighteenth century it was first the intelligentsia and the wealthy of the Greek diaspora that became familiar with the term 'Hellene' (Greek). It then spread throughout the social strata of the Greeks within the Ottoman Empire, on to the common folk. The revolution itself played a decisive role in uniting those who took part in it under this national term, charged as it was with the memories of a glorious and admirable past. ${ }^{19}$

This past became a part of these people's present, uniting them in battle. "Onwards, Hellenes!" was the cry of the generals to their soldiers-most of whom spoke Greek but also to a lesser degree Albanian and Vlach-as well as to Bulgarian and Serbian volunteers, ${ }^{20}$ urging them on to battle: "Onwards, Hellenes! Fight the Persians [sic] with courage!"21

With a vague sense of participating in a collective goal and knit together by a common past of 
ancestors called Hellenes (Greeks), as they started calling themselves, those warriors of varied origin slowly but surely fell into step with the notion that they shared a common heritage, customs and tradition. ${ }^{22}$ They created, that is, a national consciousness. Functioning as an intense laboratory of national consciousness, the revolution hammered into people like Karaiskakis a sense of a common identity and pride that moved along two axes rooted in the past and pointing towards the future: the Orthodox Christian faith and the glorious past of their ancestors. $^{23}$

The first axis, which excluded people belonging to other faiths from joining the revolution (though one would expect them to be at the same point of revolt) ${ }^{24}$, was almost a given and was connected to the immediate past. Having lived in a multi-national empire, under the same definition which the Ottoman Empire had imposed upon them, that is, part of the millet of Orthodox Christians, the steady and tried point of reference and identity for the participants in the 1821 revolution was precisely their Orthodox Christian faith.

The second axis, though this too obviously referred to the past, was also linked to the future: through the uniting element of nationalism, History rushed in and stood firmly by the side of the individual and collective myth of the rebelling Greeks, adding quality and a new dimension to their lives. When Karaiskakis, as ever in his own rude way, pointed out to the silihtar Boda that the Greeks despised their conquerors "now and forever," he was participating-both on the individual and group level -in the wondrous and reviving sense of a link to the past. With this new identity, Karaiskakis himself, as well as his fellow-soldiers, tapped the self-confidence they needed in order to confront the Ottoman administrative and military machine.

For now, due to the new spirit of nationalism, Karaiskakis and his simple and uneducated fellowwarriors felt they were morally superior to their enemies: in contrast to themselves, the Ottoman officials, military commanders and soldiers did not belong to a national group sharing a common history, sense of identity and pride, but to a camp of Turks, Albanians and Arabs united only by the medieval thread of servitude and subservience to the sovereign. ${ }^{25}$ In contrast to themselves, their enemies did not belong to a group that went back in time with all the sense of freedom and collectivity that it brings, but to a group brought together on the shallow basis of the transient and the self-serving, with all the feelings of slavery and crude self-interest it creates.

The sense of moral superiority possessed by the forces of a nation-to-be over the powers defending an empire is apparent in Karaiskakis's words even in the profuse profanity he employed. Karaiskakis entered the epoch of active nationalism fighting and, as was his characteristic, cursing. In the annals of history, however, he is remembered for his fighting. 


\section{Glossary}

The definitions of the terms used during the Ottoman rule and the revolution in this article were taken from the glossary in N. Diamandouros (ed.), Hellenism, and $\mathrm{H}$. Inalçik, History of the Ottoman Empire; the Classical Age, 1300-1600., London 1973.

* klephts: Greek outlaws or bandits who developed into a distinct military and social group, often with considerable influence among the masses.

* silihtar (or silahdar): a custodian of the sultan's weapons.

* kapak: a pact of submission negotiated by a member of the Greek ruling elite, especially the military portion of that elite, with Ottoman officialdom.

*reaya: the tax-paying subject of the Ottoman Empire, as distinct from the ruling military class.

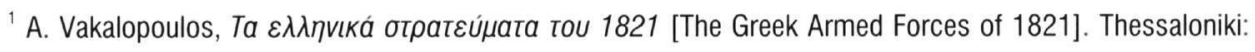
Vanias Publications, 1991, pp. 15-19.

${ }^{2}$ G. Finlay, the Scottish historian and fellow soldier of the Greeks during the 1821 Revolution, writes in his book History of the Greek Revolution and the Reign of King Otto, reprinted by Zeno Publications, London 1971, "[...] degraded as the condition of the Greeks was politically, it is probable that a larger proportion could read and write than among any other Christian race in Europe. The Greeks of every class have always set a higher value on a knowledge of letters than any other people [...]"(p.16). For the far-reaching influence of Greek education and language on the Balkans in the 18th and 19th century see R. Clogg, "The Greek Millet in the Ottoman Empire" in B. Braude and B. Lewis (eds.), Christians and Jews in the Ottoman Empire. New York: Holmes and Meir Publications, 1982, vol. I, pp. 188-190 and P. Mackridge's "The Greek Intelligentsia 1780-1830: a Balkan Perspective," in R. Clogg (ed.), Balkan Society in the Age of Greek Independence. New Jersey: Barnes and Noble Publications, 1981.

${ }^{3}$ For more on the life and work of G. Karaiskakis see D. Ainian's O Kapaïoкáknৎ [Karaiskakis], 1834

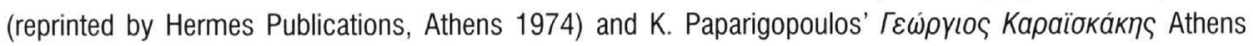
1867.

${ }^{4}$ This messenger is mentioned elsewhere as Tahir and also as Tahir aga and Karatahir; he was in the

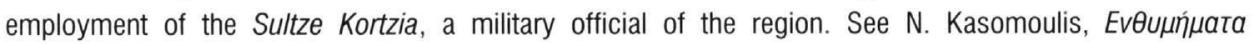

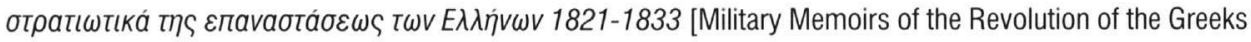
1821-1833]. Athens, 1939, vol. I, pp. 306, 308-9. He should not be confused with the Moslem Albanian official Tahir Abbaz (well known and revered by contemporary Greeks) since Kasomoulis, himself a fighter in the Revolution and well informed on people and events, refers to him as "some Karatahir" (Kasomoulis,

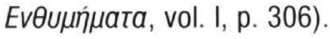

${ }^{5}$ Kasomoulis, Eveuumínata, vol. I, p. 308.

${ }^{6}$ For more on the events and Karaiskakis' stance during the time in question, in addition to information on the general practice of the kapak pacts made by the chieftains of central Greece, see. A. Vakalopoulos,

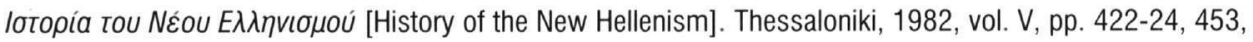
vol. VI, pp. 176, 317, 329-334, 349, 525, 549-555. Also see J. Petropoulos, "Forms of Collaboration with the Enemy during the First Greek War of Liberation" in N. P. Diamandouros (ed.), Hellenism and the First Greek War of Liberation (1821-1830): Continuity and Change. Thessaloniki: Institute for Balkan Studies,

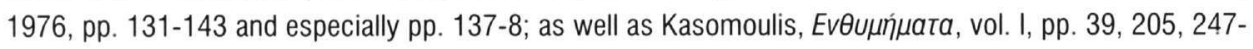
8, 266, 322-3, 337, 344-6, 365, $381 \mathrm{ff} ., 401-3$; and Vol. II, pp. 50, 333-4. A detailed description of the kapak 


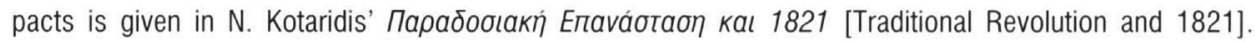
Athens: Plethron Publications, 1993, p. $171 \mathrm{ff}$.

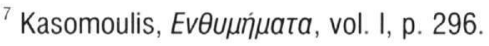

${ }^{8}$ For example, when referring to a Moslem, Kasomoulis says, "[...] although a Turk by religion [...]"

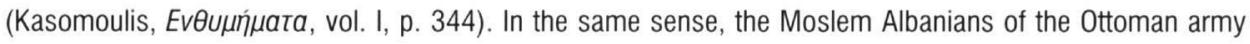
are referred to during this time as "Turcalbanians", despite the fact that racially they have nothing to do with the Turks.

${ }^{9}$ L. S. Stavrianos, The Balkans since 1453. New York, 1959, pp. 146-9, 367-9. H. Gibb and H. Bowen in Islamic Society and the West. Oxford: Oxford University Press, 1965, vol. I, part II, p. 234 mention the following: "It was only in areas where either the Moslems were distinguished by a provincial name-such as Bosnia and Albania-or where a special regime was in force-such as the principalities-that the dhimmis were recognized as being of a race distinct from the Greek."Similarly, F. Chrysanthakopoulos or Fotakos, a fighter

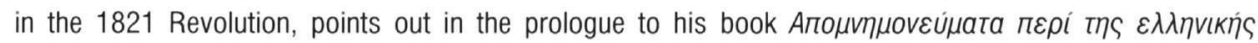

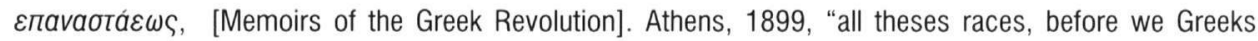
revolted, were called Greeks or Graikoi [...]"

${ }^{10}$ For more on the position of the dhimmis, see B. Braude and B. Lewis, Christians, vol. I, p. $3 \mathrm{ff}$., and H. Gibb and H. Bowen, Islamic, vol. I, part II, p. $207 \mathrm{ff}$.

${ }^{11}$ For the armatoloi and their relations with the inhabitants of the armatolik and the Turks, see. N. Kotaridis, Парабобıакі́, chapters I, II; also see Riki van Boeschoten, From Armatolik to People's Rule. Amsterdam : A. Hakkert Publications, 1991.

${ }^{12}$ See footnote \# 6 .

${ }^{13}$ ibid.

${ }^{14}$ For the contempt of the Ottoman officials towards the common Turk see L. S. Stavrianos, The Balkans, p. 93. Ziya Gökalp, the theoretician of Turkish nationalism, in his classic work, The Principles of Turkism, first published in Ankara 1920 and reprinted by E. J. Brill Publications, Leiden 1968, stresses on p. 28, "[...] The ruling cosmopolitans became the Ottoman class and the ruled Turks the Turkish class. The two classes did not love each other. The Ottoman class regarded itself as the superior nation and viewed as a subject nation the Turks whom it ruled. The Ottomans always called the Turk 'the stupid Turk'. Whenever an official personage visited a Turkish village, everyone fled shouting, 'The Ottoman is coming!'”

${ }^{15}$ For the significance of the Albanians in the Ottoman army and administration from the 17th century onwards see L. S. Stavrianos, The Balkans, pp. 501-2 and H. Gibb and H. Bowen, Islamic, vol I, part I, p. 165.

${ }^{16}$ B. Braude and B. Lewis, Christians, pp. 8-9. Avigdor Levy, in his book, The Sephardim in the Ottoman Empire. Princeton: Darwin Press, 1992, pp. 40-1, mentions, "The word 'çifüt', miser, was an insult reserved by Turks specifically for Jews. In fact, the very word 'Yahudi', Jew, was often used contemptuously in popular vernacular and, when addressed to non-Jews, was meant as an insult."One of the leaders of the

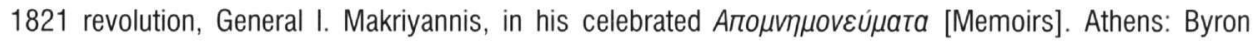
Publications, pp. 256, 280, makes mention of the use of the word 'Jew' by the Turks and Greeks as a curse synonymous with 'coward.' Thus, the Turkish besiegers of the Acropolis in Athens curse the Greeks besieged within calling them, "[...] cowardly and Jews" and elsewhere, in the description of a battle, Makriyannis says of the Turks, "We got the best of them and we had them under out thumb like Jews [...]."For more on the prejudices in general of the Christian, Moslem and Armenian subjects of the Ottoman empire concerning the Jews, see A. Galante, "Les Juifs dans le proverbe, le conte et la chanson orientaux" in his own book Histoire des Juifs de Turquie, Istanbul: Isis Publications, vol. IX, pp. 133-50. 
For the stance of the Jews during the Greek revolution see the article by M. Efthymiou, "Official Ideology and Lay Mentality during the Greek Revolution", under publication in the Annals of the International Congress, The Jewish Communities in the Balkans and Turkey in the $19^{\text {th }}$ and $20^{\text {th }}$ centuries through the end of World War II. Tel Aviv: Tel Aviv University, Diaspora Research Institute, 1995.

${ }^{17}$ P. F. Sugar, Southeastern Europe under Ottoman Rule, 1354-1804. University of Washington Press, 1977, pp. 77, 86, 103.

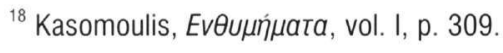

${ }^{19}$ Concerning the use of the term 'Hellene' during the Greek revolution, see J. T. Kakridis' article: "The ancient Greeks and the Greeks of the War of Independence" in Balkan Studies 4 (1963), pp. 251-264, is very illuminating. For the role of the Greek Diaspora in the process of the birth of the Greek Nation, see D. J. Geanakoplos, "The Diaspora Greeks: the Genesis of Modern Greek National Consciousness", in N. P. Diamandouros (ed.), Hellenism, pp. 59-77.

${ }^{20}$ For more on the Serbian, Montenegrin and Bulgarian fellow-soldiers of the Greeks in the 1821 revolution,

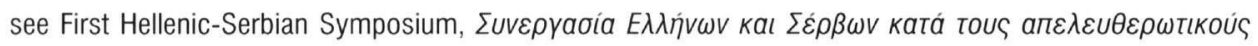

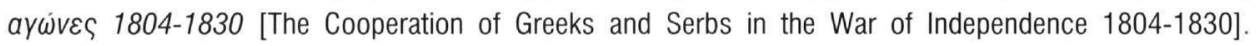
Thessaloniki: Institute for Balkan Studies, 1979, mainly the articles by E. G. Protopsaltis, " $\Sigma \varepsilon ́ p \beta o$ kal

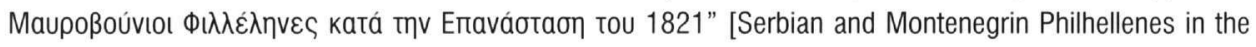

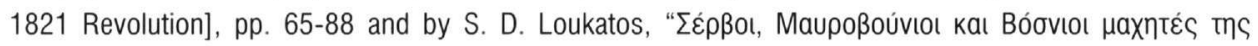

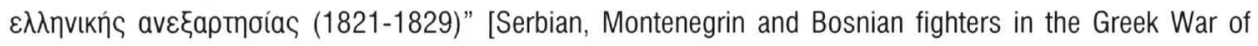
Independence], pp. 101-151. N. Todorov's book Bulgares participants dans les luttes pour la liberation de la Grèce 1821-1828, [in Bulgarian; later published in Greek]. Sofia: Academie Bulgare des Sciences, Institut d' Etudes Balkaniques, 1971, remains important.

${ }^{21}$ Theodoros Kolokotronis, leader of the armed forces in the region of the Peloponnese, would encourage

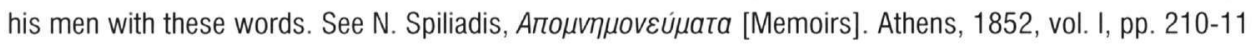
footnote 2. In the same way Nikitas Stamatelopoulos shouts at the retreating Turks during a battle, "[...] why

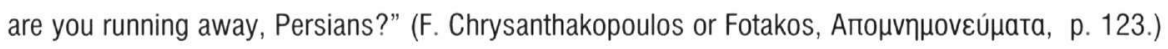

${ }^{22}$ Ioannis Philimon, fighter in the 1821 revolution and historian, in the prologue of his work $\triangle$ oki $\mu$ เov $\pi \varepsilon \rho i$

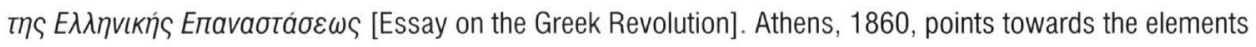
which, in his opinion, comprised the sense of community amongst the Greeks during the Revolution: "[...] thus they shared a common origin, religion, language, adversities they had suffered under Ottoman tyranny, and their hatred towards this tyranny [...]"

Theodoros Kolokotronis sums his own experience in terms of the changes the revolution brought to Greek society: "[...] the society of people was small; it was only the Revolution that brought us together as Greeks."

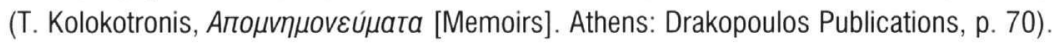

The revolution absorbed into the Greek nation many of the Slav fellow-fighters of the Greeks. Thus, Gligoris Tjourovitz in 1828 asks the first Governor of Greece, loannis Kapodistrias, to employ him, "in the service of the mother country" as a reward for the labours he suffered for the sake of this beloved homeland" (E. G. Protopsaltis, " $\Sigma \varepsilon \dot{\varepsilon} \beta$ ßo", p. 88), while in 1827 the local revolutionary authorities of Sparta, where he had fought, had already supplied him with a document certifying that he had fought, "with zeal and patriotism"

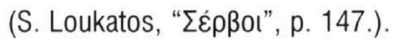

${ }^{23}$ An indicative example is the rhetoric used in the proclamations distributed during the struggle for

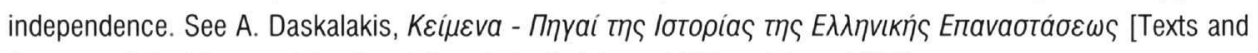
Sources of the History of the Greek Revolution]. Athens 1966, vol. I, p. $143 \mathrm{ff}$. 
${ }^{24}$ As was the case with the Albanians during the outbreak of the Greek revolution (N. Botzaris, Visions balkaniques dans la préparation de la Revolution Grecque 1789-1821. Paris 1962, pp. 167-176) and with the Greek-speaking Catholic inhabitants of the Aegean islands (K. Metaxas, "Ібторıкá Апо

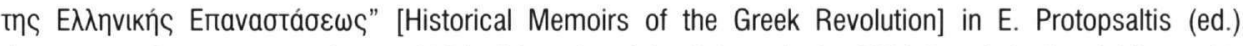

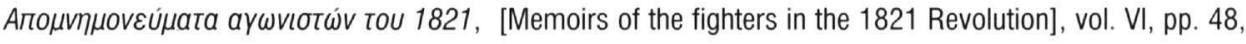
$50,53,56,57,137$.

${ }^{25}$ G. Finlay, History of the Greek Revolution, p. 308, commenting on the opposing camps during the Revolution writes, "Both were supported by strong feelings of religious and national antipathy, but the strength of the Greek cause lay in the hearts of the people and that of the Turks in the energy of the sovereign $[\ldots] "$ 